\title{
Effectiveness of Injecting Cold 5\% Dextrose into Patients with Nerve Damage Symptoms during Thyroid Radiofrequency Ablation
}

\author{
Min Kyoung Lee ${ }^{1,2}$, Jung Hwan Baek ${ }^{1}$, Sae Rom Chung ${ }^{1}$, Young Jun Choi ${ }^{1}$, Yu-Mi Lee ${ }^{3}$, Tae Yong Kim ${ }^{4}$, Jeong Hyun Lee ${ }^{1}$ \\ ${ }^{1}$ Department of Radiology and Research Institute of Radiology, Asan Medical Center, University of Ulsan College of Medicine; \\ ${ }^{2}$ Department of Radiology, Yeouido St. Mary's Hospital, College of Medicine, The Catholic University of Korea; ${ }^{3}$ Department of \\ Surgery, ${ }^{4}$ Division of Endocrinology \& Metabolism, Department of Internal Medicine, Asan Medical Center, University of Ulsan \\ College of Medicine, Seoul, Korea
}

Background: Although radiofrequency ablation (RFA) is a safe treatment for thyroid tumors, nerve damage is a frequent complication. A previous retrospective study suggested that an injection of cold $5 \%$ dextrose in water $(5 \% \mathrm{DW})$ can reduce nerve damage during RFA. This study validated the efficacy of injecting cold 5\% DW for management of nerve damage during RFA.

Methods: Between November 2017 and December 2018, 242 patients underwent 291 RFA sessions for treatment of benign thyroid nodules or recurrent thyroid cancers. Using a standardized technique, cold $\left(0^{\circ} \mathrm{C}\right.$ to $\left.4{ }^{\circ} \mathrm{C}\right) 5 \% \mathrm{DW}$ was immediately injected around the damaged nerve into patients with any symptoms suggesting nerve damage. The incidence of nerve damage, the volume of $5 \%$ DW injected, symptom recovery time and the incidence of permanent nerve damage were evaluated.

Results: Nineteen patients experienced nerve damage symptoms related to 21 RFA sessions, including 17 patients during 19 sessions and two patients on the day after two sessions. Patients with nerve damage symptoms detected during RFA were treated by injection of a mean $41 \mathrm{~mL}$ (range, 3 to 260) cold 5\% DW, but the two patients who experienced symptoms the next day did not receive cold 5\% DW injections. Immediate recovery was observed after 15 RFA sessions in 14 patients. No patient experienced permanent nerve damage.

Conclusion: Injection of cold 5\% DW is effective in managing nerve damage during RFA of thyroid lesions.

Keywords: Thyroid nodule; Radiofrequency ablation; Ultrasonography

\section{INTRODUCTION}

Ultrasonography (US)-guided radiofrequency ablation (RFA) is an alternative treatment for benign thyroid nodules and recurrent thyroid cancers [1,2]. Previous studies [3-11], including meta-analyses, showed that RFA is safe, with a low incidence of

Received: 30 December 2019, Revised: 2 April 2020, Accepted: 13 May 2020

Corresponding author: Jung Hwan Baek

Department of Radiology and Research Institute of Radiology, Asan Medical Center, University of Ulsan College of Medicine, 88 Olympic-ro 43-gil, Songpagu, Seoul 05505, Korea

Tel: +82-2-3010-4348, Fax: +82-2-476-0090, E-mail: radbaek@naver.com complications. Among patients undergoing RFA for benign thyroid nodules and recurrent thyroid cancers, the incidences of overall complications have been reported to be $2.1 \%$ and $11.0 \%$, respectively, and the incidences of major complications $1.3 \%$ and $6.7 \%$, respectively [12]. Complications can include nerve damage symptoms, such as voice changes, Horner syndrome,

Copyright $(\odot 2020$ Korean Endocrine Society

This is an Open Access article distributed under the terms of the Creative Commons Attribution Non-Commercial License (https://creativecommons.org/ licenses/by-nc/4.0/) which permits unrestricted non-commercial use, distribution, and reproduction in any medium, provided the original work is properly cited. 
limitations of shoulder movement, and palpitations, which must be carefully managed to avoid permanent sequelae [7,9].

Complications during RFA can be minimized by better understanding of nerve anatomy and by methods such as the movingshot technique, hydrodissection and using a small-sized electrode tip $(0.38$ to $0.5 \mathrm{~cm})$ [1,13-15]. However, no standard management method has yet been introduced for complications (e.g., voice changes). Although one previous retrospective study suggested that injection of 5\% cold dextrose in water (DW) solution around the damaged nerve can mitigate nerve damage during RFA [16], this has not been validated. The present study evaluated the efficacy of injecting 5\% cold DW using a standardized technique [16] into patients with symptoms of nerve damage during RFA.

\section{METHODS}

This retrospective study was approved by the Institutional Review Boards (2019-0783) of Asan Medical Center. Written informed consent by the patients was waived due to a retrospective nature of our study.

\section{Study population}

Between November 2017 and December 2018, 242 patients, including 48 men and 194 women, of mean age 50.9 \pm 15.7 years, underwent RFA for US-guided biopsy-proven benign thyroid nodules causing cosmetic or symptomatic problems [1] or biopsy-proven recurrent thyroid cancers. The study population consisted of the subset of these patients who experienced nerve-related complications.

\section{RFA technique}

RFA was performed according to the guidelines of the Korean Society of Thyroid Radiology [1]. US-guided biopsy samples were obtained by radiologists under the supervision of three staff radiologists who had 10 years (Y.J.C.), 21 years (J.H.L.), and 25 years (J.H.B.) of experience with thyroid US. US-guided RFA was performed by three staff radiologists. RFA was performed using an RF generator (VIVA RF generator, STARmed, Goyang, Korea; and M-2004, RF Medical, Seoul, Korea) and 18-gauge thyroid dedicated modified internally cooled electrodes (VIVA, STARmed; and RFT-0710, RF Medical) with multiple active tips $(3.8,5,7$, and $10 \mathrm{~mm})$. The size of the active tip selected was dependent on the size of the thyroid lesion [2].

To reduce pain, $2 \%$ lidocaine was injected into the perithyroidal or perilesional area and at the skin puncture site [1,2]. RFA of benign nodules was performed using the trans-isthmic approach and the moving-shot technique, whereas RFA of recurrent cancers was performed using the moving-shot and hydrodissection techniques [17-20]. Adjacent structures were carefully monitored and hydrodissection was performed to minimize nerve damage in patients undergoing RFA for recurrent cancers. Hydrodissection consisted of a continuous injection of cold 5\% DW to separate critical structures, including the nerve and esophagus, from the thyroid tumors [2,21,22]. Safety margins during RFA were preserved by continuous fluid injection, as injected fluid spreads along and is absorbed by the muscle plane. RFA was terminated when the entire targeted lesion became transiently hyperechoic [1]. Patient symptoms, especially nerve damage symptoms, were monitored during RFA. Patients were evaluated in the hospital for 30 minutes after RFA.

\section{Definition of complications and side effects}

Major and minor complications, as well as side effects, were classified according to the guidelines of the Society of Interventional Radiology [7,9,23]. Major complications were those that led to substantial morbidity or disability, requiring hospital admission or increased hospital stay. Major complications in this study included voice changes and shoulder weakness lasting over 1 month. All other complications, including voice changes lasting less than 1 month and hematoma that induced an acute symptom or required medication, were defined as minor complications. Side effects were defined as signs and symptoms not requiring therapy or prescription medications, as well as any undesired consequences of RFA. Following the reporting in previous studies [7,9], transient voice change due to lidocaine injection was regarded as neither complications nor side effects.

\section{Management of suspected nerve damage}

Nerve damage symptoms evaluated during RFA included voice changes, Horner syndrome, palpitations, limitations of shoulder movement, and paresthesia. Because the recurrent laryngeal nerve is the nerve most frequently affected during RFA $[3,6,8,9$, $16]$, voice changes during RFA were monitored regularly. Voice changes can also be induced by injury to the vagus nerve. Horner syndrome can be induced by injury to the cervical sympathetic ganglion, and limitations to shoulder movement can be induced by injury to the spinal accessory nerve $[3,9,16]$. We regularly monitored voice changes, symptoms of Horner syndrome (i.e., injection of conjunctiva), and shoulder movement during RFA, especially during ablation near critical structures (e.g., nerves, trachea, and esophagus). Patients' vital signs, including 
heart rate, blood pressure, and oxygen saturation, were also monitored. Cold 5\% DW was prepared before ablation, allowing immediate injection when nerve symptoms appeared. Ablation was stopped immediately in patients with nerve damage symptoms detected during RFA. To manage nerve damage and reduce its progression, cold $\left(0^{\circ} \mathrm{C}\right.$ to $\left.4^{\circ} \mathrm{C}\right) 5 \% \mathrm{DW}$ was injected into the area around the damaged nerve (Fig. 1) [16]. Cold 5\% DW at $0^{\circ} \mathrm{C}$ to $4^{\circ} \mathrm{C}$ was chosen because it was isotonic and did not conduct electricity [24]. Using a $21 \mathrm{G}$ spinal needle, cold 5\% DW was injected continuously into the tracheoesophageal groove, the most common course of the recurrent laryngeal nerve [25], and the site of suspected nerve injury, until patient recovery from voice changes. Additional fluid was injected after recovery from voice changes to reduce thermal injury caused by residual heat. We did not include this extra volume of additionally injected cold 5\% DW in the measurement of the injected volume. Nerve symptoms were monitored the next day by telephone, with follow-up calls repeated until complete symptom relief. Oral corti-
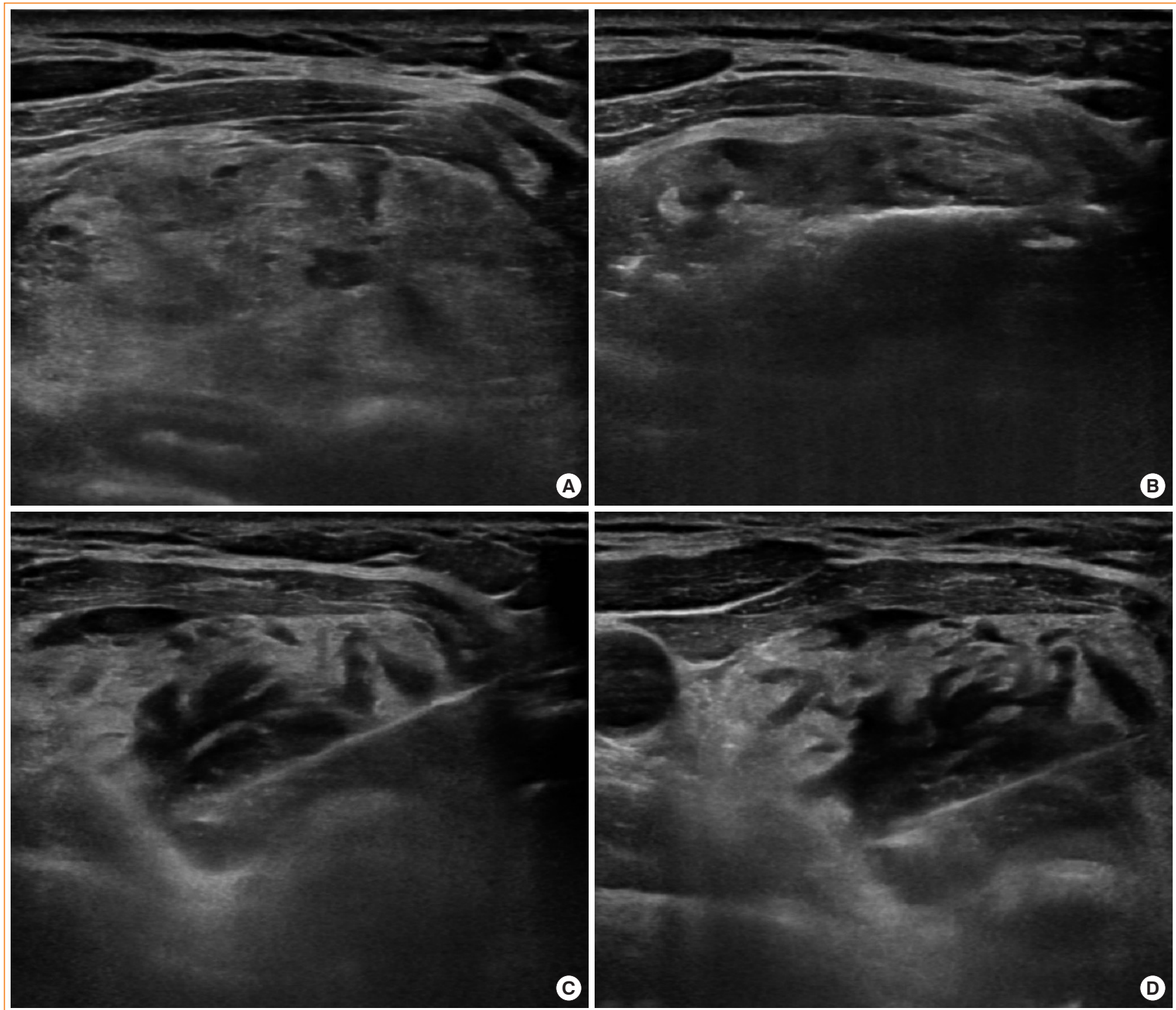

Fig. 1. (A) Ultrasonography showing a benign thyroid nodule $(1.7 \times 3.8 \times 4.5 \mathrm{~cm})$ in the left isthmic thyroid gland. (B) Radiofrequency electrode with a $1 \mathrm{~cm}$ sized active tip located within the nodule for ablation. (C) During ablation, the patient complained of voice changes; ablation was immediately stopped and cold 5\% dextrose water was injected into the left tracheoesophageal groove. (D) After injection of $20 \mathrm{~mL}$ cold 5\% dextrose water, the voice change was completely relieved. 
costeroids were prescribed for patients who did not recover from voice changes or other nerve damage symptoms after injection of cold $5 \% \mathrm{DW}$, but were not prescribed for patients who experienced immediate symptom relief after injection of cold $5 \%$ DW. Parameters evaluated included the incidence of nerve damage, the volume of cold 5\% DW injected, symptom recovery time, and the incidence of permanent nerve damage. We defined immediate recovery of a nerve symptom as symptom relief a

Table 1. Demographic and Clinical Characteristics of the Study Population

\begin{tabular}{|c|c|c|c|}
\hline \multirow[b]{2}{*}{ Characteristic } & \multicolumn{2}{|c|}{ Pathology } & \multirow[b]{2}{*}{$\begin{array}{c}\text { Total } \\
(n=242)\end{array}$} \\
\hline & $\begin{array}{l}\text { Benign } \\
\text { thyroid } \\
\text { nodules } \\
(n=177)\end{array}$ & $\begin{array}{c}\text { Recurrent } \\
\text { thyroid } \\
\text { cancers } \\
(n=65)\end{array}$ & \\
\hline Age, yr & $48.2 \pm 13.5$ & $58.2 \pm 18.6$ & $50.9 \pm 15.7$ \\
\hline \multicolumn{4}{|l|}{ Gender } \\
\hline Male & $23(13.0)$ & $25(38.5)$ & $48(19.8)$ \\
\hline Female & $154(87.0)$ & $40(61.5)$ & $194(80.2)$ \\
\hline Total no. of sessions $\mathrm{s}^{\mathrm{a}}$ & 200 & 91 & 291 \\
\hline 1 & $138(69.0)$ & $74(81.3)$ & $212(72.9)$ \\
\hline 2 & $45(22.5)$ & $10(11.0)$ & $55(18.9)$ \\
\hline$>3$ & $17(8.5)$ & $7(7.7)$ & $24(8.2)$ \\
\hline Total energy, $\mathrm{J}^{\mathrm{a}}$ & $33.8 \pm 16.5$ & $13.6 \pm 9.0$ & $27.5 \pm 17.4$ \\
\hline Mean volume, $\mathrm{mL}^{\mathrm{a}}$ & $14.0 \pm 14.5$ & $19.2 \pm 86.0$ & $15.5 \pm 46.8$ \\
\hline Mean diameter, $\mathrm{cm}^{\mathrm{a}}$ & $3.9 \pm 2.3$ & $1.6 \pm 2.0$ & $3.2 \pm 2.5$ \\
\hline \multicolumn{4}{|l|}{ Location $^{\mathrm{a}}$} \\
\hline Right thyroid lobe & $86(43.0)$ & NA & $86(29.6)$ \\
\hline Left thyroid lobe & $102(51.0)$ & NA & $102(35.1)$ \\
\hline Isthmus & $12(6.0)$ & NA & $12(4.1)$ \\
\hline Operation bed & NA & $35(38.5)$ & $35(12.0)$ \\
\hline Level II & NA & $11(12.1)$ & $11(3.8)$ \\
\hline Level III & NA & $8(8.8)$ & $8(2.7)$ \\
\hline Level IV & NA & $8(8.8)$ & $8(2.7)$ \\
\hline Level V & NA & $1(1.1)$ & $1(0.3)$ \\
\hline Level VI & NA & $13(14.3)$ & $13(4.5)$ \\
\hline Supraclavicular lymph node & NA & $6(6.6)$ & $6(2.1)$ \\
\hline Stenocleidomastoid muscle & NA & $2(2.2)$ & $2(0.7)$ \\
\hline Paraspinal muscle & NA & $1(1.1)$ & $1(0.3)$ \\
\hline Axillar lymph node & NA & $2(2.2)$ & $2(0.7)$ \\
\hline Preauricular lymph node & NA & $3(3.3)$ & $3(1.0)$ \\
\hline Suprasternal area & NA & $1(1.1)$ & $1(0.3)$ \\
\hline
\end{tabular}

Values are expressed as mean \pm standard deviation or number (\%). NA, not applicable.

${ }^{a}$ Session based number. few minutes after starting cold 5\% DW injection.

\section{RESULTS}

The 242 patients, including 177 with benign nodules and 65 with recurrent thyroid cancers (papillary thyroid cancer, 62 patients; medullary thyroid carcinoma, three patients), underwent a total of 291 RFA sessions, including 212 (72.9\%) single sessions. Table 1 shows the demographic and clinical characteristics of these patients. Mean thyroid nodule volume was 15.5土 $46.8 \mathrm{~mL}$ (range, 0.1 to 178 ), and mean total RF energy was $27.5 \pm 17.4 \mathrm{~J}$ (range, 5 to 90 ).

Complications and side effects of RFA are summarized in Table 2 . The incidences of major and minor complications were $2.1 \%$ and $6.5 \%$, respectively. Voice change was the most common major complication $(50 \%, 3 / 6)$. Table 3 shows cases of suspected nerve damage during and after RFA. Nineteen patients experienced nerve damage during and after 21 sessions of RFA (20 voice changes and one limitation of arm elevation). Two patients with recurrent tumors in the operation bed each experienced voice problems on two occasions.

Table 2. Complications and Side Effects of Radiofrequency Ablation

\begin{tabular}{lcccc}
\hline Complication & $\begin{array}{c}\text { SIR } \\
\text { class }\end{array}$ & $\begin{array}{c}\text { Total } \\
\text { sessions } \\
(n=291)\end{array}$ & $\begin{array}{c}\text { Benign } \\
\text { nodules } \\
(n=200)\end{array}$ & $\begin{array}{c}\text { Recurrent } \\
\text { cancers } \\
(n=91)\end{array}$ \\
\hline Major complications $^{\mathrm{a}}$ & & 6 & 3 & 3 \\
Voice change $>1 \mathrm{mo}^{\text {Skin burn }}$ & $\mathrm{C}$ & 3 & 2 & 1 \\
Grave's disease & $\mathrm{E}$ & 1 & 0 & 1 \\
Spinal accessory nerve injury & $\mathrm{b}$ & 1 & 0 & 1 \\
Minor complications & $\mathrm{E}$ & 1 & 1 & 0 \\
Voice change $<1$ mo & $\mathrm{B}$ & 19 & 8 & 11 \\
Hematoma & $\mathrm{B}$ & 2 & 2 & 0 \\
Side effects & & 16 & 13 & 3 \\
Pain & $\mathrm{NA}$ & 10 & 8 & 2 \\
Hematoma & $\mathrm{NA}$ & 4 & 4 & 0 \\
Vasovagal reaction & $\mathrm{NA}$ & 2 & 1 & 1 \\
\hline
\end{tabular}

SIR classification: A (no therapy, no consequence), B (nominal therapy, no consequence; includes overnight admission for observation only), $\mathrm{C}$ (requires therapy, minor hospitalization $<48$ hours), D (requires therapy, unplanned increase in level of care, prolonged hospitalization $>48$ hours), E (permanent adverse sequelae), F (death).

SIR, Society of Interventional Radiology; NA, not applicable.

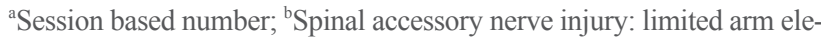
vation. 
Fig. 2 shows a flowchart of the patients included in this study. Of the 19 patients who experienced nerve damage symptoms during and after 21 RFA sessions, 17 patients experienced nerve damage symptoms during 19 RFA sessions and two patients ex-

\begin{tabular}{|c|c|c|c|c|c|c|c|c|c|c|c|}
\hline Patient & Age & Sex & Pathology & Location & $\begin{array}{l}\text { Size, } \\
\mathrm{cm}\end{array}$ & Symptom & $\begin{array}{l}\text { Symptom } \\
\text { onset }\end{array}$ & SIR classification & $\begin{array}{l}\text { Injection of } \\
\text { cold dextrose } \\
\text { solution, mL }\end{array}$ & Steroid & $\begin{array}{c}\text { Time interval } \\
\text { until symptom } \\
\text { improvement }\end{array}$ \\
\hline 1 & 67 & Female & $\begin{array}{l}\text { Recurrent } \\
\text { PTC }\end{array}$ & $\begin{array}{l}\text { Right operation } \\
\text { bed }\end{array}$ & 1.2 & Voice change & $\begin{array}{c}\text { During } \\
\text { RFA }\end{array}$ & Minor complication & Yes, 7 & No & $\begin{array}{l}\text { Immediate after } \\
\text { injection }\end{array}$ \\
\hline 2 & 79 & Female & $\begin{array}{l}\text { Recurrent } \\
\text { PTC }\end{array}$ & $\begin{array}{l}\text { Right operation } \\
\text { bed }\end{array}$ & 0.5 & Voice change & $\begin{array}{c}\text { During } \\
\text { RFA }\end{array}$ & Minor complication & Yes, 35 & No & $\begin{array}{l}\text { Immediate after } \\
\text { injection }\end{array}$ \\
\hline 3 & 66 & Female & $\begin{array}{l}\text { Recurrent } \\
\text { PTC }\end{array}$ & $\begin{array}{l}\text { Left operation } \\
\text { bed }\end{array}$ & 0.6 & Voice change & $\begin{array}{c}\text { During } \\
\text { RFA }\end{array}$ & Minor complication & Yes, 60 & No & $\begin{array}{l}\text { Immediate after } \\
\text { injection }\end{array}$ \\
\hline 4 & 36 & Male & $\begin{array}{l}\text { Recurrent } \\
\text { PTC }\end{array}$ & $\begin{array}{l}\text { Left operation } \\
\text { bed }\end{array}$ & 0.4 & Voice change & $\begin{array}{c}\text { During } \\
\text { RFA }\end{array}$ & Minor complication & Yes, 50 & No & $\begin{array}{l}\text { Immediate after } \\
\text { injection }\end{array}$ \\
\hline 5 & 74 & Female & $\begin{array}{l}\text { Recurrent } \\
\text { PTC }\end{array}$ & $\begin{array}{l}\text { Right operation } \\
\text { bed }\end{array}$ & 1.0 & Voice change & $\begin{array}{c}\text { During } \\
\text { RFA }\end{array}$ & Minor complication & Yes, 40 & No & $\begin{array}{l}\text { Immediate after } \\
\text { injection }\end{array}$ \\
\hline 6 & 66 & Female & $\begin{array}{l}\text { Recurrent } \\
\text { PTC }\end{array}$ & $\begin{array}{l}\text { Right operation } \\
\text { bed }\end{array}$ & 1.7 & Voice change & $\begin{array}{c}\text { During } \\
\text { RFA }\end{array}$ & Minor complication & Yes, 20 & No & $\begin{array}{l}\text { Immediate after } \\
\text { injection }\end{array}$ \\
\hline 7 & 59 & Female & $\begin{array}{l}\text { Benign } \\
\text { nodule }\end{array}$ & Right thyroid & 3.6 & Voice change & $\begin{array}{c}\text { During } \\
\text { RFA }\end{array}$ & Minor complication & Yes, 15 & No & $\begin{array}{l}\text { Immediate after } \\
\text { injection }\end{array}$ \\
\hline 8 & 36 & Female & $\begin{array}{l}\text { Benign } \\
\text { nodule }\end{array}$ & Left thyroid & 1.2 & Voice change & $\begin{array}{c}\text { During } \\
\text { RFA }\end{array}$ & Minor complication & Yes, 3 & No & $\begin{array}{l}\text { Immediate after } \\
\text { injection }\end{array}$ \\
\hline 9 & 35 & Male & $\begin{array}{c}\text { Benign } \\
\text { nodule }\end{array}$ & Left thyroid & 4.5 & Voice change & $\begin{array}{c}\text { During } \\
\text { RFA }\end{array}$ & Minor complication & Yes, 20 & No & $\begin{array}{l}\text { Immediate after } \\
\text { injection }\end{array}$ \\
\hline 10 & 61 & Female & $\begin{array}{l}\text { Benign } \\
\text { nodule }\end{array}$ & Left thyroid & 4.3 & Voice change & $\begin{array}{c}\text { During } \\
\text { RFA }\end{array}$ & Minor complication & Yes, 5 & No & $\begin{array}{l}\text { Immediate after } \\
\text { injection }\end{array}$ \\
\hline 11 & 58 & Female & $\begin{array}{l}\text { Benign } \\
\text { nodule }\end{array}$ & Right thyroid & 5.8 & Voice change & $\begin{array}{c}\text { During } \\
\text { RFA }\end{array}$ & Minor complication & Yes, 40 & No & $\begin{array}{l}\text { Immediate after } \\
\text { injection }\end{array}$ \\
\hline \multirow[t]{2}{*}{12} & 45 & Female & $\begin{array}{l}\text { Recurrent } \\
\text { MTC }\end{array}$ & $\begin{array}{l}\text { Left operation } \\
\text { bed }\end{array}$ & 0.8 & Voice change & $\begin{array}{c}\text { During } \\
\text { RFA }\end{array}$ & Minor complication & Yes, 20 & No & $\begin{array}{l}\text { Immediate after } \\
\text { injection }\end{array}$ \\
\hline & 45 & Female & $\begin{array}{l}\text { Recurrent } \\
\text { MTC }\end{array}$ & $\begin{array}{l}\text { Left operation } \\
\text { bed }\end{array}$ & 0.6 & Voice change & $\begin{array}{c}\text { During } \\
\text { RFA }\end{array}$ & Minor complication & Yes, 17 & No & $\begin{array}{l}\text { Immediate after } \\
\text { injection }\end{array}$ \\
\hline 13 & 26 & Female & $\begin{array}{l}\text { Benign } \\
\text { nodule }\end{array}$ & Right thyroid & 2.9 & Voice change & $\begin{array}{c}\text { During } \\
\text { RFA }\end{array}$ & Minor complication & Yes, 20 & No & $\begin{array}{l}\text { Immediate after } \\
\text { injection }\end{array}$ \\
\hline \multirow[t]{2}{*}{14} & 27 & Female & $\begin{array}{l}\text { Recurrent } \\
\text { PTC }\end{array}$ & $\begin{array}{l}\text { Right operation } \\
\text { bed }\end{array}$ & 0.4 & Voice change & $\begin{array}{c}\text { During } \\
\text { RFA }\end{array}$ & Minor complication & Yes, 40 & No & $\begin{array}{l}\text { Immediate after } \\
\text { injection }\end{array}$ \\
\hline & 27 & Female & $\begin{array}{l}\text { Recurrent } \\
\text { PTC }\end{array}$ & $\begin{array}{l}\text { Left operation } \\
\text { bed }\end{array}$ & 0.4 & Voice change & $\begin{array}{c}\text { During } \\
\text { RFA }\end{array}$ & Minor complication & Yes, 15 & Yes & $1 \mathrm{wk}$ \\
\hline 15 & 58 & Female & $\begin{array}{l}\text { Recurrent } \\
\text { PTC }\end{array}$ & $\begin{array}{l}\text { Left operation } \\
\text { bed }\end{array}$ & 1.1 & Voice change & $\begin{array}{c}\text { During } \\
\text { RFA }\end{array}$ & Minor complication & Yes, 100 & Yes & $2 \mathrm{wk}$ \\
\hline 16 & 64 & Female & $\begin{array}{l}\text { Recurrent } \\
\text { PTC }\end{array}$ & Right level II & 0.5 & Voice change & $\begin{array}{c}\text { During } \\
\text { RFA }\end{array}$ & Major complication & Yes, 15 & Yes & $1 \mathrm{mo}$ \\
\hline 17 & 47 & Male & $\begin{array}{l}\text { Benign } \\
\text { nodule }\end{array}$ & Left thyroid & 3.1 & Voice change & $\begin{array}{c}\text { During } \\
\text { RFA }\end{array}$ & Major complication & Yes, 260 & Yes & 50 day \\
\hline 18 & 62 & Female & $\begin{array}{l}\text { Benign } \\
\text { nodule }\end{array}$ & Left thyroid & 3.6 & Voice change & Next day & Major complication & No & No & $1 \mathrm{mo}$ \\
\hline 19 & 66 & Female & $\begin{array}{l}\text { Recurrent } \\
\text { PTC }\end{array}$ & Right level II & 3.9 & $\begin{array}{l}\text { Spinal accessory } \\
\text { nerve injury }\end{array}$ & Next day & Major complication & No & No & $3 \mathrm{mo}$ \\
\hline
\end{tabular}




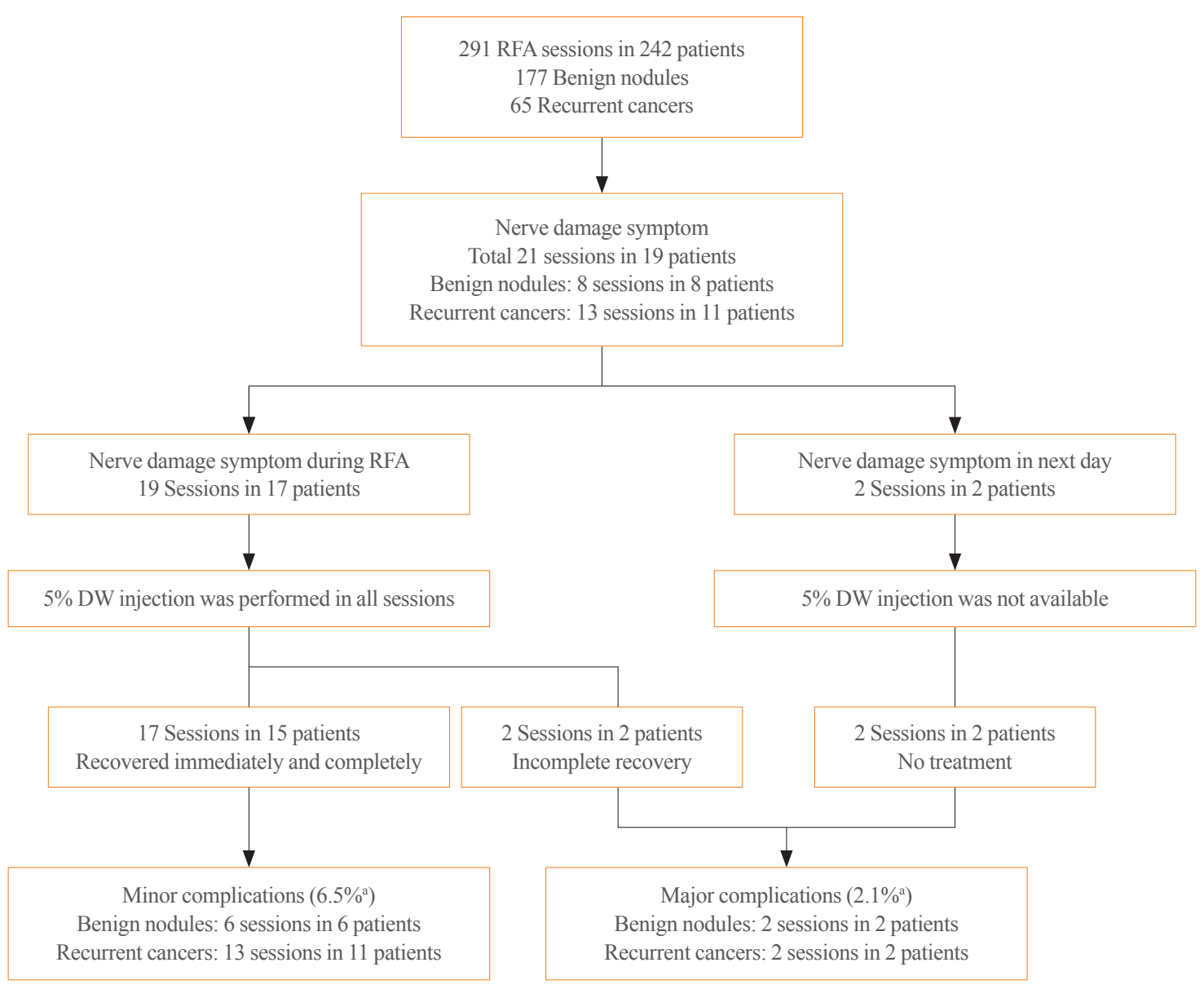

Fig. 2. Study flow diagram. There are four major complications, including three in the recurrent laryngeal nerves and one in the spinal accessory nerve. RFA, radiofrequency ablation; DW, dextrose water. ${ }^{a}$ Session based percentage.

perienced nerve damage symptoms the day after two RFA sessions. Cold 5\% DW solution was injected into all patients with nerve damage symptoms during RFA, but not in the two patients with symptoms the next day. The mean volume of cold $5 \%$ DW solution injected during the 19 sessions was $41 \mathrm{~mL}$ (range, 3 to 260). Injection of cold 5\% DW resulted in immediate recovery during 15 of the 19 sessions. The two patients with delayed detection of nerve damage symptoms recovered after 1 and 3 months later. No patient experience permanent nerve damage.

The left operation bed (6/21 sessions) was the most frequent location of nerve damage, followed by the left thyroid gland (5/21 sessions) and the right operation bed (5/21 sessions). The injured nerves included the recurrent laryngeal nerve $(n=19$, $90 \%)$, the vagus nerve $(n=1,5 \%)$, and the spinal accessory nerve $(n=1,5 \%)$. Of the 19 patients with suspected nerve damage, 11 had recurrent cancers, and eight had benign nodules.

\section{DISCUSSION}

This study demonstrated that patients with nerve damage during RFA were managed successfully by injection of cold 5\% DW. Nineteen patients (7.9\%) experienced nerve damage symptoms (voice change or shoulder weakness) during 21 sessions (7.2\%) of RFA. Cold 5\% DW was injected into 17 patients during 19 RFA sessions, with immediate complete recovery observed in 14 patients (82.4\%) during 15 RFA sessions (78.9\%). By contrast, the two patients who did not receive injections of cold 5\% DW recovered after 1 and 3 months. The immediate symptom relief resulting from cold 5\% DW injection may have been due to its initial cooling of the damaged nerve and its reduction of additional conductive heat transfer to the nerve. The injection of cold 5\% DW into peritumoral soft tissue may result in complete treatment of thyroid masses during RFA, as it is effective in treating thermal nerve damage.

A previous study, the first to assess the efficacy of cold 5\% 
DW for treatment of thermal nerve damage, also found that this solution provided rapid symptom relief [16]. Although that study assessed the effectiveness of cold 5\% DW injection, the standardized method of injection was not evaluated. By contrast, the present study evaluated the injection of cold 5\% DW using a standardized technique [16]. Nerve symptoms were regularly evaluated during RFA, including voice changes, conjunctival injection, ptosis, palpitations, and shoulder movement. Because immediate injection is important for the relief of thermal nerve injury, cold 5\% DW was prepared before RFA was started. As soon as any suspicious nerve symptom appeared, ablation was stopped and cold 5\% DW was injected at the site of suspected nerve injury. Most injections were into the tracheoesophageal groove, because the most frequently involved nerve was the recurrent laryngeal nerve $(90 \%)$. The standardized injection was effective in treating nerve damage. The mean volume of injected cold 5\% DW was $41 \mathrm{~mL}$, with an additional 10 to $20 \mathrm{~mL}$ [16] provided to the targeted site, as the injected fluid spread along the muscle plane and was rapidly absorbed into the surrounding space [21]. Strong compression of the RFA site after RFA is not recommended as it enhances conductive heat transfer. Rather, we routinely performed applying smooth pressure to the needle puncture site. Corticosteroids have been shown to reduce perineural edema and inflammatory changes after thyroid operations, because the recurrent laryngeal nerve may be mechanically injured and cause dissection during thyroid operations [26,27]. Oral corticosteroids were therefore prescribed to patients who did not recover from voice changes or other nerve damage symptoms after cold 5\% DW injection, but not to patients who experienced immediate symptom relief after injection of cold $5 \%$ DW.

US-guided RFA is an effective and safe treatment for benign thyroid nodules and recurrent thyroid cancers [18,21]. Despite its many advantages, this technique has several important complications [2]. The most serious complication is thermal nerve injury, as it may cause permanent sequelae after RFA, especially voice changes [7,9]. Recurrent thyroid cancers are more difficult to ablate than benign thyroid nodules, because the former are smaller and have no safety margins of normal thyroid tissue $[2,3]$. The rate of nerve damage was higher in patients undergoing RFA for recurrent thyroid cancer than for benign thyroid nodules $[7,9]$. This study showed that injection of cold $5 \% \mathrm{DW}$ was effective for rapid improvement of nerve damage and that it reduced the rate of permanent sequelae after RFA. Effective control of nerve damage using cold 5\% DW can result in higher rates of safe and curative ablation for recurrent thyroid cancer.
Reduced rates of nerve damage and effective treatment of nerve damage are important for successful ablation of thyroid nodules. Nerve damage during RFA may be reduced by early detection of symptoms and skilled injection of cold 5\% DW. We found that delayed detection of nerve damage may cause long standing symptoms and permanent sequelae. For early detection of nerve damage, we routinely performed repeated monitoring of patient symptoms. The most common symptom of nerve damage is voice change, usually caused by injury to the recurrent laryngeal and vagus nerves $[3,7,9,13]$. Anatomic determination of nerve structure is recommended for ablation near the nerves and skilled injection of cold 5\% DW. The recurrent laryngeal nerve is usually located in the tracheoesophageal groove and passes along the posteromedial sides of both thyroid glands [13]. The vagus nerve is located within the carotid sheath, passing to the posterolateral side of the common carotid artery and the posteromedial side of the internal jugular vein $[14,15]$. Anatomic variations of the vagus nerve, including anterior, medial, and posterior types, bring the nerve closer to the thyroid gland, possibly increasing the risk of thermal nerve damage during RFA [9]. Careful control of the electrode tip for ablation of tumors near the tracheoesophageal groove and carotid sheath is recommended, as is detailed understanding of the anatomic locations of perithyroidal structures.

This study had several limitations. First, complications and side effects were evaluated symptomatically, based on subjective complaints by patients, not on objective and quantitative criteria. The objective evaluation of symptoms such as voice change during RFA is limited, because methods such as vocal cord examination are difficult to perform during RFA. Evaluation of the vocal cords on US may help to detect vocal cord palsy, and can therefore be useful for evaluating symptom relief after cold DW injection. We will update our technique to incorporate US evaluation of the vocal cords. Second, RFA of thyroid tumors was performed by three skilled technicians. Nerve damage may be reduced by RFA being performed by more experienced individuals with better understanding of perithyroidal anatomic structures. Third, the number of patients with nerve damage was small, making it difficult to determine whether our technique should be adapted as standard treatment. Large-sized prospective studies are required to determine a standard treatment strategy for patients experiencing thermal nerve injury during RFA.

In conclusion, this study showed that injection of cold $5 \%$ DW was effective in managing suspected nerve damage during RFA. This technique is effective in controlling thermal damage 
to nerves, and may encourage curative ablation for recurrent thyroid cancer.

\section{CONFLICTS OF INTEREST}

No potential conflict of interest relevant to this article was reported.

\section{AUTHOR CONTRIBUTIONS}

Conception or design: M.K.L., J.H.B., S.R.C., Y.J.C., J.H.L. Acquisition, analysis, or interpretation of data: M.K.L., J.H.B., S.R.C., Y.J.C., Y.M.L., T.Y.K., J.H.L. Drafting the work or revising: M.K.L., J.H.B. Final approval of the manuscript: M. K.L., J.H.B.

\section{ORCID}

Min Kyoung Lee https://orcid.org/0000-0003-3172-3159

Jung Hwan Baek https://orcid.org/0000-0003-0480-4754

\section{REFERENCES}

1. Kim JH, Baek JH, Lim HK, Ahn HS, Baek SM, Choi YJ, et al. 2017 Thyroid radiofrequency ablation guideline: Korean Society of Thyroid Radiology. Korean J Radiol 2018;19:63255.

2. Park HS, Baek JH, Park AW, Chung SR, Choi YJ, Lee JH. Thyroid radiofrequency ablation: updates on innovative devices and techniques. Korean J Radiol 2017;18:615-23.

3. Chung SR, Suh CH, Baek JH, Park HS, Choi YJ, Lee JH. Safety of radiofrequency ablation of benign thyroid nodules and recurrent thyroid cancers: a systematic review and metaanalysis. Int J Hyperthermia 2017;33:920-30.

4. Na DG, Lee JH, Jung SL, Kim JH, Sung JY, Shin JH, et al. Radiofrequency ablation of benign thyroid nodules and recurrent thyroid cancers: consensus statement and recommendations. Korean J Radiol 2012;13:117-25.

5. Mauri G, Cova L, Monaco CG, Sconfienza LM, Corbetta S, Benedini S, et al. Benign thyroid nodules treatment using percutaneous laser ablation (PLA) and radiofrequency ablation (RFA). Int J Hyperthermia 2017;33:295-9.

6. Jung SL, Baek JH, Lee JH, Shong YK, Sung JY, Kim KS, et al. Efficacy and safety of radiofrequency ablation for benign thyroid nodules: a prospective multicenter study. Korean J Radiol 2018;19:167-74.
7. Baek JH, Lee JH, Sung JY, Bae JI, Kim KT, Sim J, et al. Complications encountered in the treatment of benign thyroid nodules with US-guided radiofrequency ablation: a multicenter study. Radiology 2012;262:335-42.

8. Wang JF, Wu T, Hu KP, Xu W, Zheng BW, Tong G, et al. Complications following radiofrequency ablation of benign thyroid nodules: a systematic review. Chin Med J (Engl) 2017;130:1361-70.

9. Kim C, Lee JH, Choi YJ, Kim WB, Sung TY, Baek JH. Complications encountered in ultrasonography-guided radiofrequency ablation of benign thyroid nodules and recurrent thyroid cancers. Eur Radiol 2017;27:3128-37.

10. Sim JS, Baek JH. Long-term outcomes following thermal ablation of benign thyroid nodules as an alternative to surgery: the importance of controlling regrowth. Endocrinol Metab (Seoul) 2019;34:117-23.

11. Chung SR, Baek JH, Sung JY, Ryu JH, Jung SL. Revisiting rupture of benign thyroid nodules after radiofrequency ablation: various types and imaging features. Endocrinol Metab (Seoul) 2019;34:415-21.

12. Deveci MS, Deveci G, LiVolsi VA, Baloch ZW. Fine-needle aspiration of follicular lesions of the thyroid: diagnosis and follow-up. Cytojournal 2006;3:9.

13. Ha EJ, Baek JH, Lee JH. Ultrasonography-based thyroidal and perithyroidal anatomy and its clinical significance. Korean J Radiol 2015;16:749-66.

14. Giovagnorio F, Martinoli C. Sonography of the cervical vagus nerve: normal appearance and abnormal findings. AJR Am J Roentgenol 2001;176:745-9.

15. Knappertz VA, Tegeler CH, Hardin SJ, McKinney WM. Vagus nerve imaging with ultrasound: anatomic and in vivo validation. Otolaryngol Head Neck Surg 1998;118:82-5.

16. Chung SR, Baek JH, Choi YJ, Lee JH. Management strategy for nerve damage during radiofrequency ablation of thyroid nodules. Int J Hyperthermia 2019;36:204-10.

17. Lee JH, Kim YS, Lee D, Choi H, Yoo H, Baek JH. Radiofrequency ablation (RFA) of benign thyroid nodules in patients with incompletely resolved clinical problems after ethanol ablation (EA). World J Surg 2010;34:1488-93.

18. Baek JH, Kim YS, Lee D, Huh JY, Lee JH. Benign predominantly solid thyroid nodules: prospective study of efficacy of sonographically guided radiofrequency ablation versus control condition. AJR Am J Roentgenol 2010;194:1137-42.

19. Baek JH, Moon WJ, Kim YS, Lee JH, Lee D. Radiofrequency ablation for the treatment of autonomously functioning thyroid nodules. World J Surg 2009;33:1971-7.

Copyright (C) 2020 Korean Endocrine Society 
20. Jeong WK, Baek JH, Rhim H, Kim YS, Kwak MS, Jeong HJ, et al. Radiofrequency ablation of benign thyroid nodules: safety and imaging follow-up in 236 patients. Eur Radiol 2008;18:1244-50.

21. Lim HK, Baek JH, Lee JH, Kim WB, Kim TY, Shong YK, et al. Efficacy and safety of radiofrequency ablation for treating locoregional recurrence from papillary thyroid cancer. Eur Radiol 2015;25:163-70.

22. Shin JH, Baek JH, Ha EJ, Lee JH. Radiofrequency ablation of thyroid nodules: basic principles and clinical application. Int J Endocrinol 2012;2012:919650.

23. Sacks D, McClenny TE, Cardella JF, Lewis CA. Society of Interventional Radiology clinical practice guidelines. J Vasc Interv Radiol. 2003 Sep;14(9 Pt 2):S199-202.

24. Laeseke PF, Sampson LA, Brace CL, Winter TC 3rd, Fine JP, Lee FT Jr. Unintended thermal injuries from radiofre- quency ablation: protection with 5\% dextrose in water. AJR Am J Roentgenol 2006;186(5 Suppl):S249-54.

25. Mohil RS, Desai P, Narayan N, Sahoo M, Bhatnagar D, Venkatachalam VP. Recurrent laryngeal nerve and voice preservation: routine identification and appropriate assessment: two important steps in thyroid surgery. Ann R Coll Surg Engl 2011;93:49-53.

26. Wang LF, Lee KW, Kuo WR, Wu CW, Lu SP, Chiang FY. The efficacy of intraoperative corticosteroids in recurrent laryngeal nerve palsy after thyroid surgery. World J Surg 2006; 30:299-303.

27. Emre A, Karadeniz Cakmak G, Karakaya Arpaci D, Uygun Ilikhan S, Damar M. The efficacy of intraoperative single dose methylprednisolone on recurrent laryngeal nerve function after thyroidectomy. Int Surg 2016;101:116-20. 